\title{
ENDOLYMPHATIC SAC SURGERY AND POSTERIOR SEMICIRCULAR CANAL FENESTRATION FOR MENIERE'S DISEASE
}

\author{
Ilija S. Filipche', Marina Davcheva Chakar², Venko Filipche ${ }^{3}$, Sijavash Javari² \\ ${ }^{1}$ Macedonian Academy of Sciences and Arts, Skopje, RN Macedonia \\ ${ }^{2}$ University Clinic for Otorhinolaryngology, Faculty of Medicine, University Ss. Cyril and Methodius, Skopje, RN Macedonia \\ ${ }^{3}$ University Clinic for Neurosurgery, Faculty of Medicine, University Ss. Cyril and Methodius, Skopje, RN Macedonia
}

Corresponding author: Ilija S. Filipche, Macedonian Academy of Sciences and Arts, Skopje, N. Macedonia; e-mail: ilijafilipce@yahoo.com

\section{ABSTRACT}

Objective: To evaluate the efficiency and safety of the simultaneous endolymphatic sac drainage (ELSD) and posterior semicircular canal fenestration (PSCF) primary on the vestibular function as an new therapeutic strategy in the patients with medically refractory Meniere's disease (MD).

Study Design: retrospective follow-up study.

Setting: University Clinic of Otolaryngology.

Methods: Twenty-six patients with MD with severe vertigo and disability who underwent ELSD and PSCF in the same time in the period of 1988 and 2007 were reviewed. The main outcome measures were frequency of vertigo, functional disability according the guidelines for diagnosis and evaluation of therapy in MD. The canal paresis was evaluated by caloric test. The degree of reduced vestibular response rates as an indicators of the vestibular function were compared before and after surgery.

Results: The preoperative audition was already altered in all cases except in 8 patients who had no significant changes in hearing threshold. The mean value of vertigo attacks before operation was 8.6. After 3 years of surgery only one patient $(3.8 \%)$ had one vertigo attack. Functional level was highly ameliorated except in two patients who presented functional level 2 or B in the late postoperative period. The mean caloric testing duration after 3 years postoperatively showed that the $50 \%$ of the patients approaching the normal results.

Conclusion: Based on the results of simultaneous endolymphatic sac surgery and posterior canal fenestration, they are effective methods for treatment of the refractory Meniere's disease. Endolymphatic sac surgery enables drainage of endolymphatic fluid and the fenestration of the posterior semicircular canal enables the distension or dilatation of the membranous canal in the decompressed perilymphatic space across the perilymphatic leak at the level of the new fenestra, and, so, appearing of certain decrease of the endolymphatic pressure. Both techniques at the same time decrease the pressure in the case of the endolymphatic hydrops.

Keywords: Meniere's disease, refractory vertigo, endolymphatic sac surgery, posterior semicircular canal fenestration

\section{INTRODUCTION}

Few procedures in otological surgery have been as controversial as endolymphatic sac surgery for Meniere's disease. Opinions regarding the efficacy of this procedure vary from those who conclude that the procedure is effective in over $80 \%$ of cases to those who believe that the 
procedure is not better than a placebo or sham procedure $[1,2]$. Despite this controversy, most clinicians recommend endolymphatic sac surgery because it is a nondestructive procedure that can be performed as an outpatient basis $[3,5]$. Endolymphatic sac procedure offers the possibility of vertigo control with little risk of morbidity. Theoretically, endolymphatic sac surgery offers improves the function of a scarified endolymphatic sac or opens a blocked endolymphatic duct. Consequently, the pressure of the endolymh in the endolymphatic space is throught to decrease.

Recently, another type of surgical method has been developed for control of vertigo in Meniere's disease: the semicircular canal plugging, which aims to ablate endolymphatic movement in the occluded canal [6]. Several studies suggest that this method should be one of the therapeutic option for intractable vertigo in Meniere's disease $[7,8]$.

In this study, we examined the simultaneous effects of posterior semicircular canal fenestration and endolymphatic sac drainage primary on vestibular and cochlear function as a new therapeutic strategy for disabling Meniere's disease.

\section{MATERIALS AND METHODS}

This study revealed twenty-six patients with debilitating vertigo symptoms who underwent simultaneous endolymphatic sac surgery (ELSD) and fenestration of the posterior semicircular canal (PSCF) at the University Clinic of Otolaryngology, Medical faculty Skopje, between 1988 and 2007. All patients met criteria for definite Meniere's disease as established by the American Academy of Otolaryngology-Head and Neck Surgery criteria $[9,10]$. The diagnosis of the Meniere's disease was based on a careful history, including a neurotologic history and physical examination, audiometry, vestibular testing, laboratory testing, and imaging methods. In all patients, the appropriate medical management with diet, diuretics, vestibular suppressants, steroids or vasoactive agents has failed to control the vertigo attacks, and all of them chose and decided to have a surgical treatment. Every patient was informed carefully about the surgical and functional risks and also about the other options of surgical treatments.

\section{Hearing}

Hearing level was documented by audiometry. The mean sensory-neural hearing loss (SNHL) was quantified using the formula: SNHL $(\mathrm{dB})=(2 \mathrm{x}$ hearing loss at $1 \mathrm{kHz}+4 \mathrm{x}$ hearing loss at $2 \mathrm{kHz}+1 \mathrm{x}$ hearing loss at $4 \mathrm{kH})$.

\section{Vestibular function}

The vestibular function was assessed through the frequency of vertigo, functional disability and caloric test.

Frequency of vertigo - FV

The frequency of vertigo attacks before surgery has been compared with the frequency of the attacks occurring between 6 and 36 months after the surgery. The vertigo control was established according the criteria of AAO-HNS, using the formula:

Y-FV - is the average number of definitive spells per month for six months before therapy

$\mathrm{X}-\mathrm{FV}-$ is the average number of definitive spells per month for 18 to 36 months after therapy

Results:

(X/Y) x 100

The results have been noted on a scale of $\mathrm{A}$ (complete control) to F (no control) [10].

\section{Functional disability}

The functional disability was self-assed by the patients before and after the surgery on a scale of 1 (no disability) to 6 (permanent disability) according to the criteria of modified version of the AAO- HNS functional scale [10].

\section{Caloric test}

The vestibular function was assessed with caloric test. All the patients included in this study had both preoperative and postoperative caloric testing. The caloric test procedure consisted of standard bithermal irrigation.

\section{Statistics}

Categorical variables are present with absolute and relative numbers. Descriptive statistics for continual variables are calculating the mean values, standard deviation (SD), standard error (SE) median, minimal and maximal values. 
Statistical analysis has been done with the following tests: Wilcoxon Matched Paris test, $t$ test for dependent samples. For the level of significance was used $\mathrm{p}<0.05$.

\section{Surgical Procedures}

The ELSD and PSCF surgery was performed under general anesthesia with retroauricular approach by the senior author of the study. Our technique involved limited antro-mastoidectomy and facial and posterior semicircular canal identification, followed by skeletonization of the posterior fossa dura and complete decompression of the sac. Maximum bone removal in the infra-labyrinthine compartment was stressed. The lateral aspect of the sac was incised, and the sac and duct were probed. A thin Silastic sheet was placed into the sac extending into the mastoid cavity. A subarachnoid shunt was employed in two patients.

The second surgery step was drilled around the dome of the posterior semicircular canal with a small diamond burr and isolating the dome at about $2.5 \times 5 \mathrm{~mm}$ up to the blue line. After the blue line was visible, the dome was removed, as an eggshell would be, with a sickle knife and without injuring the membranous labyrinthine. The fenestra and surrounding bone were covered with a piece of skin graft. The osteogenesis-inhibitory effect of the squamous epithelium is well understood in the cholesteatoma, and we used this to inhibit neo-osteogenesis on the fenestration site. The incision closure and postoperative early follow-up were standard.

\section{RESULTS}

The patients group included 17 men and 9 women. The age range of the patients who underwent surgery was 27 to 59 years (mean 45.7 years). The average number of years from the onset of symptoms until the time of surgery was four years (3 to 6 years). The initial symptom in 14 patients was violent whirling vertigo. Tinnitus of a low frequency type and a fluctuating hearing loss accounted for the main complaint in the remaining 12 patients. The seventeen surgical procedures were on the right, and another 9 on the left ear. There were no surgical complications.

Table 1. Frequency of vertigo

\begin{tabular}{|c|c|c|c|c|c|c|}
\hline \multirow{2}{*}{$\begin{array}{c}\text { Number of vertigo } \\
\text { attacks }\end{array}$} & \multicolumn{2}{|c|}{$\begin{array}{c}6 \text { months before } \\
\text { operation }\end{array}$} & \multicolumn{2}{|c|}{6 months after operation } & \multicolumn{2}{|c|}{$\begin{array}{l}3 \text { years after } \\
\text { operation }\end{array}$} \\
\hline & $\mathrm{N}$ & $\%$ & $\mathrm{~N}$ & $\%$ & $\mathrm{~N}$ & $\%$ \\
\hline 0 & l & / & 21 & 80.8 & 23 & 88.5 \\
\hline 1 & l & / & 1 & 3.8 & 2 & 7.7 \\
\hline 2 & 1 & I & 2 & 7.7 & 1 & 3.8 \\
\hline 3 & / & / & 2 & 7.7 & l & l \\
\hline 4 & 2 & 7.7 & / & I & I & I \\
\hline 5 & 5 & 19.3 & / & / & I & I \\
\hline 7 & 3 & 11.5 & l & l & l & l \\
\hline 8 & 7 & 26.9 & / & I & / & l \\
\hline 9 & 1 & 3.8 & / & / & / & l \\
\hline 10 & 5 & 19.3 & I & / & I & I \\
\hline 12 & 1 & 3.8 & / & I & I & I \\
\hline 15 & 2 & 7.7 & I & I & 1 & 1 \\
\hline total & 26 & 100 & 26 & 100 & 26 & 100 \\
\hline
\end{tabular}

6 months before $/ 6$ months after - Wilcoxon Matched Pairs $Z=4.46 p=0.000008(p<0.001)$

6 months after/ 3 years after according to Wilcoxon Matched Pairs $Z=1.62 p=0.11 \mathrm{NS}$ 


\section{Hearing}

The preoperative audition was already altered in all cases. The audiometric evaluation of our study group gave the following results: in 10 patients $(38.5 \%)$ a recovery greater than $10 \mathrm{db}$ was registered, another seven patients $(27 \%)$ experienced hearing threshold worsening greater than $10 \mathrm{db}$ and 8 patients $(30.7 \%)$ had no significant hearing threshold changes. Only one case of postoperative deafness was noticed $(3.8 \%)$.

Vestibular function

Frequency of vertigo

The results for the frequency of vertigo are presented in Table 1 and Figure 1.

According to the results, there is evidently a high statistical significance in reducing the vertigo attacks frequency after 6 months postoperatively, while in the period from 6 months to 3 years, the differences in the frequency of the vertigo attacks show a low statistical significance.

\section{Functional level}

The preoperative functional level confirmed severe stage of the disease in all cases. After the surgery the functional level was highly ameliorated, except in 6 patients who presented functional level 2 in the early postoperative period. After the period of 3 years only 2 patients (7.7\%) presented functional level 2 or B. Another 24 patients $(92.3 \%)$ were completely asymptomatic (level 1).

The results show significant improving of the functional level in the first 6 months postoperatively. Improving of the function level in the period from 6 months to 3 years was not of statistical significance.

\section{Caloric testing}

After endolymphatic sac surgery and fenestration of the posterior canal the patients presented decrease of the canal paresis.

Table 3 shows the distribution (absolute and relative) of the caloric testing duration among the patients at three time-points: preoperatively, 6 months and 3 years after surgery.

Tables 3, 3.1, 4, and 4.1 present the descriptive data of the mean caloric test duration by calculating the mean values (mean), standard deviation (SD), lowest and highest duration, as well as median value (median).

The average caloric testing duration is $78.0 \pm 8.6 \mathrm{sec}$ preoperatively, $85.8 \pm 14.2 \mathrm{sec}, 6$ months and $93.8 \pm 13.2 \mathrm{sec}$ postoperatively. The minimal test duration is ranging from $60 \mathrm{sec}$ preoperatively and 6 months postoperatively till 70 sec, 3 years post operatively. The maximal test duration is ranging from $90 \mathrm{sec}$ preoperatively till $110 \mathrm{sec}$ at the control testing 6 months and 3 years postoperatively. The mean testing duration shows that $50 \%$ of the patients had caloric test duration longer than $80 \mathrm{sec}$ preoperatively, 90 sec 6 months, and $100 \mathrm{sec}, 3$ years postoperatively (approaching the normal results).

The tested differences between the average caloric test duration analyzed preoperatively, 6 months and 3 years postoperatively, show high statistical significance $(p<0.01)$.

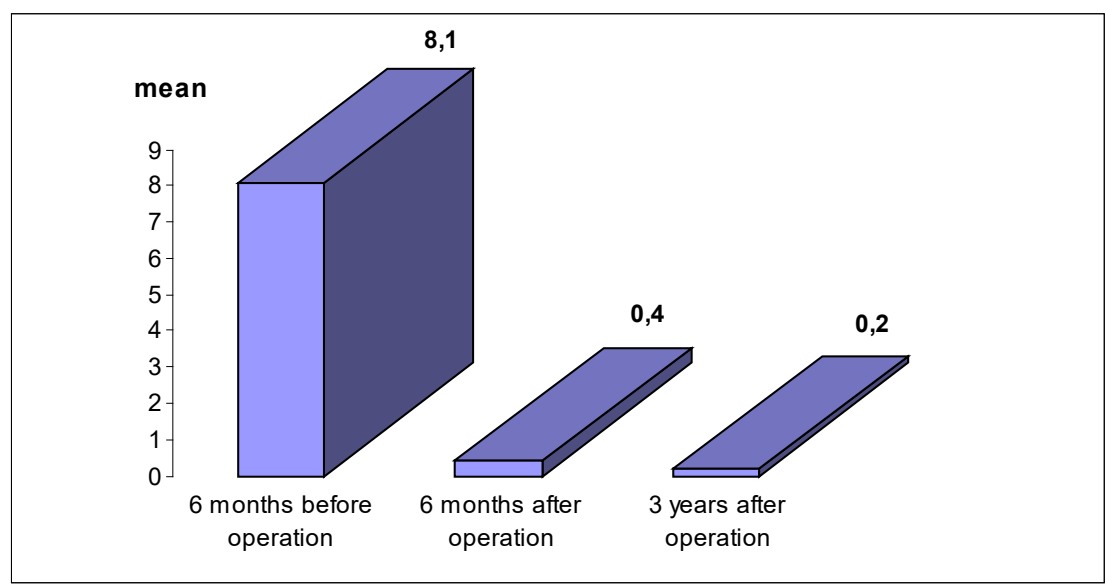

Fig.1 Average number of vertigo attacks 
Table 2. Functional level 6 months before operation, 6 months and 3 years after operation

\begin{tabular}{|c|c|c|c|c|c|c|}
\hline FL & $\mathbf{6}$ months before operation & \multicolumn{2}{|c|}{ 6 months after operation } & \multicolumn{2}{|c|}{ 3 years after operation } \\
\hline 1 & N & $\%$ & N & $\%$ & N & $\%$ \\
\hline 2 & $/$ & $/$ & 20 & 76.9 & 24 & 92.3 \\
\hline 5 & $/$ & $/$ & 6 & 23.1 & 2 & 7.7 \\
\hline 6 & 20 & 76.9 & $/$ & $/$ & $/$ & \\
\hline Total & 6 & 23.1 & $/$ & $/$ & $/$ & $/$ \\
\hline
\end{tabular}

6 months before $/ 6$ months after operation - Wilcoxon Matched Pairs $Z=4.46 \mathrm{p}=0.000008(\mathrm{p}<0.001)$

6 months after/ 3 years after operation - Wilcoxon Matched Pairs $Z=1.83 p=0.068$ NS

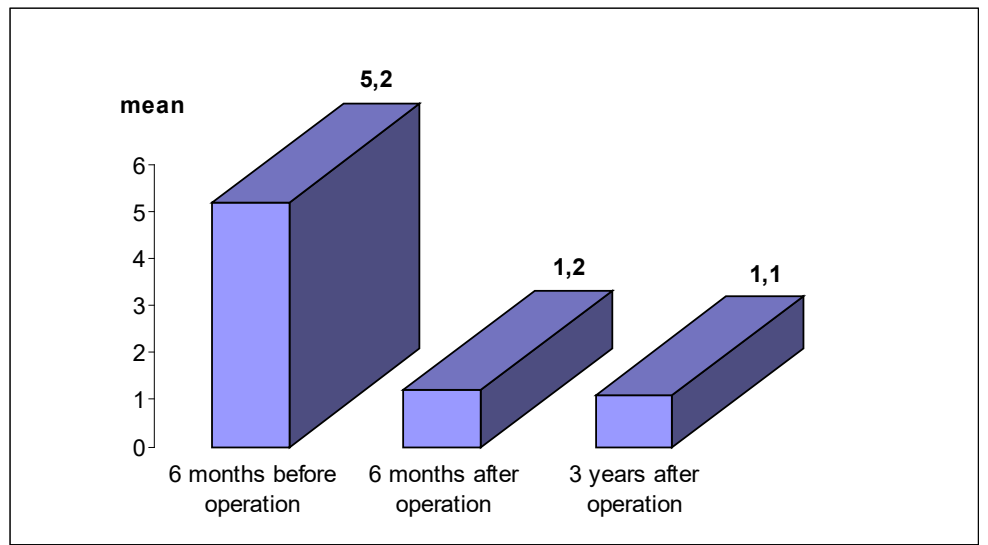

Fig. 2. Functional level of vertigo attacks

Table 3. Results from the caloric test with cold water before, early and late postoperative

\begin{tabular}{|c|c|c|c|c|c|c|}
\hline $\begin{array}{c}\text { Caloric test (sec) } \\
\text { Cold water }\end{array}$ & \multicolumn{3}{|c|}{$\begin{array}{c}\text { Before } \\
\text { operation }\end{array}$} & \multicolumn{2}{c|}{ 6 months postoperative } & \multicolumn{2}{|c|}{ 3 years postoperative } \\
\hline 60 & $\mathrm{~N}$ & $\%$ & $\mathrm{~N}$ & $\%$ & $\mathrm{~N}$ & $\%$ \\
\hline 70 & 2 & 7.69 & 2 & 7.69 & 0 & 0 \\
\hline 80 & 6 & 23.08 & 5 & 19.23 & 3 & 11.54 \\
\hline 85 & 12 & 46.15 & 5 & 19.23 & 4 & 15.38 \\
\hline 90 & 1 & 3.85 & 0 & 0 & 0 & 0 \\
\hline 100 & 5 & 19.23 & 5 & 19.23 & 5 & 19.23 \\
\hline 110 & 0 & 0 & 8 & 30.77 & 8 & 30.77 \\
\hline Total & 0 & 0 & 1 & 3.85 & 6 & 23.08 \\
\hline
\end{tabular}

Table 3-1. Mean, standard deviation, standard error, median, minimum and maximum values before, early and late after operation

\begin{tabular}{|l|l|l|l|l|l|l|l|}
\hline $\begin{array}{l}\text { Caloric test (sec)- } \\
\text { cold water }\end{array}$ & N & Mean & SD & SE & Median & Min. & Max. \\
\hline $\begin{array}{l}\text { Before operation } \\
\begin{array}{l}\text { 6 months } \\
\text { postoperative }\end{array}\end{array}$ & 26 & 78.27 & 8.6 & 1.7 & 80.0 & 60.0 & 90.0 \\
\hline $\begin{array}{l}\text { 3 years. } \\
\text { postoperative }\end{array}$ & 26 & 85.77 & 14.2 & 2.8 & 90.0 & 60.0 & 110.0 \\
\hline
\end{tabular}


Table 4. Results from the caloric test with warm water before, early and late postoperative

\begin{tabular}{|c|c|c|c|c|c|c|}
\hline $\begin{array}{c}\text { Caloric test (sec)- } \\
\text { Warm water }\end{array}$ & \multicolumn{3}{|c|}{$\begin{array}{c}\text { Before } \\
\text { operation }\end{array}$} & \multicolumn{6}{c|}{ 6 months postoperative } & \multicolumn{2}{|c|}{ 3 years postoperative } \\
\hline 50 & $\mathrm{~N}$ & $\%$ & $\mathrm{~N}$ & $\%$ & $\mathrm{~N}$ & $\%$ \\
\hline 55 & 2 & 7.69 & 0 & 0 & 0 & 0 \\
\hline 60 & 1 & 3.85 & 0 & 0 & 0 & 0 \\
\hline 70 & 11 & 42.31 & 3 & 11.54 & 0 & 0 \\
\hline 80 & 7 & 26.92 & 12 & 46.15 & 7 & 26.92 \\
\hline 90 & 4 & 15.38 & 7 & 26.92 & 11 & 42.31 \\
\hline 100 & 1 & 3.85 & 3 & 11.54 & 6 & 23.08 \\
\hline Total & 0 & 0 & 1 & 3.85 & 2 & 7.69 \\
\hline
\end{tabular}

Table 4-1. Mean, standard deviation, standard error, median, minimum and maximum duration before, early and late postoperative

\begin{tabular}{|c|c|c|c|c|c|c|c|}
\hline $\begin{array}{l}\text { Caloric test (sec)- } \\
\text { Warm water }\end{array}$ & $\mathbf{N}$ & Mean & SD & SE & Median & Min. & Max. \\
\hline Before operation & 26 & 65.96 & 10.0 & 1.9 & 60.0 & 50.0 & 90.0 \\
\hline $\begin{array}{l}6 \text { months } \\
\text { postoperative }\end{array}$ & 26 & 75.00 & 9.9 & 1.9 & 70.0 & 60.0 & 100.0 \\
\hline $\begin{array}{l}3 \text { years } \\
\text { postoperative }\end{array}$ & 26 & 81.15 & 9.1 & 1.8 & 80.0 & 70.0 & 100.0 \\
\hline \multicolumn{8}{|c|}{ t-test for dependent samples } \\
\hline \multicolumn{5}{|c|}{ Before operation/ 6 months after operation } & $\mathrm{t}=4.7$ & $\mathrm{p}=0.00008$ & Sig. \\
\hline \multicolumn{5}{|c|}{6 months and 3 years after operation } & $\mathrm{t}=3.49$ & $\mathrm{p}=0.0018$ & Sig. \\
\hline
\end{tabular}

\section{DISCUSSION}

Having stated that the exact etiology is unknown, what do we know of the Meniere's disease? Meniere's disease is a clinical disorder associated with the histopathological finding of endolymphatic hydrops [11, 12]. Many procedures have been designed for this condition for mechanical decompression of the endolymphatic space, including the Fick procedure, the Cody tack, cryosurgery, ultrasound, and otic-periotic shunt $[15,17]$. The one procedure that seems to have best survived the test of time despite controversy, however, is the endolymphatic sac decompression/drainage technique. However, the natural history of the Meniere's disease, specifically the spontaneous remission rate and the high placebo effect seen in Meniere's patients, has provoked many to question the effectiveness of endolymphatic sac procedures. Despite the con- troversies beliefs concerning the benefits of the endolymphatic sac surgery in Meniere's disease with serviceable hearing and disabling vertigo, most ENT surgeons routinely perform the procedure. The nondestructive nature of the surgery, low complication rate, minimal morbidity, and ability to perform the procedure as an outpatient are clearly advantages over other invasive procedures. For these reasons, and whit a success rate approaching $90 \%$, the endolymphatic sac surgery, with or without steroids, remains a valuable and reasonable option for treating the vertigo of Meniere's disease [18, 19].

The original idea for fenestration of the semicircular canal in Meniere's disease has very simple physiological basis. Most of the hydropic distension found in postmortem species is seen in the cochlea and the saccule, although occasionally the utricle and the ampulla semicicularis are involved. Making an analogy with the facial nerve decompression in the cases with Bell's pal- 
sy (compressive phenomenon), we put the question whether the fenestration of the semicircular canal in the cases with endolymphatic hydrops, can induce decreasing of the pressure in the endolymphatic space in some degree? Theoretically, we thought that it's possible. As to the reason why this effect is produced by the operation we have no theory to offer other that the supposition that it is by the distension or dilatation of the membranous canal in the decompressed perilymphatic space across the perilymphatic leak at the level of the new fenestra, and so appearing of certain decrease of the endolymphatic pressure. This is only symptomatic, nondestructive treatment which preserves normal membranous anatomy and function. We believe that this procedure attempts to restore the function to the inner ear, rather than destroy or decrease vestibular function. And why only the posterior semicircular canal and not the other canals? There is only one reason: it is already in the operative field. One does not need to change to another body site; therefore, it saves time and reduces the chance of complications and contamination. Our future ideas in the surgery treatment of the refractory Meniere's go toward drainage of saccus endolymphaticus and fenestration of the posterior, lateral and superior semicircular canals. Whether this surgical method should be superior in correlation with others techniques remains to be shown by the postoperative results. We expect them to be successful.

\section{CONCLUSION}

Based on our results we thought that the endolymphatic sac drainage surgery and simultaneous fenestration of the posterior semicircular canal are alternative and effective methods for patients with refractory Meniere's disease. The nondestructive nature of this operative techniques is an important factor for preservation, functional and anatomical integrity of the membranous labyrinth.

\section{REFERENCES}

1. Thomsen J, Bretlau P, et al. Placebo effect in surgery for Meniere's disease. Arch Otolaryngol 1981; 107: 271-277.
2. Bretlau P, Thomsen J, et al. Placebo effects in surgery for Meniere's disease: nine-year follow-up. Am J Otol 1989; 10: 259-261.

3. Ford CN. Results of endolymphatic sac surgery in advanced Meniere's disease. Am J Otol 1982; 3: 339-342.

4. Moffat DA. Endolymphatic sac surgery: analysis of 100 operations. Clin Otolaryngol 1994; 19: 261-266.

5. Gibson WPR. The effect of surgical removal of the extraosseous portion of the endolymphatic sac in patients suffering from Meniere's disease. J Laryngol Otol 1996; 110: 1008-1011

6. Yin S, Chen Z, Yu D, et al. Triple semicircular canal occlusion for the treatment of Meniere's disease. Acta Otolaryngol 2008; 128: 739-743

7. Charpiot A, Rohmer D, Gentine A. Lateral semicircular canal plugging in severe Meniere's disease: a clinical prospective study about 28 patients. Otology Neurotology 2010; 31: 237-240.

8. Parnes LS, McClure JA. Posterior semicircular canal occlusion in the normal hearing ear. Otolaryngol Head Neck Surg 1991; 104: 52-57.

9. Alford BR. Meniere's disease: criteria for diagnosis and evaluation of therapy for reporting. Trans Am Acad Ophtalmol Otolaryngol 1972; 76: 1462-1464

10. Monsell EM, Balkany TA, Gates GA at al. Committee on Hearing and Equilibrium guidelines for the diagnosis and evaluation of therapy in Meniere's disease. Otolaryngol Head Neck Surg 1995; 113: 181-185.

11. Shambaugh GE, Jr, Clemis JD, Arenberg IK. Endolymphatic duct and sac in Meniere's disease. Surgical and histopathologic observations. Arch Otolaryngol 1969; 89: 816-825.

12. Gibson WP, Arenberg IK. Pathophysiological theories in the etiology of Meniere's disease. Otolaryngol Clin North Am 1977; 30: 961-967.

13. Cody DTR. The shunt operation and tack operation. Can J Otolaryngol 1974; 3: 271-273.

14. Silverstein H, Smouha E, Jones R. Natural history vs. surgery for Meniere's disease. Otolaryngol Head Neck Surg 1989; 100: 6-16.

15. Huang TS. Endolymphatic sac surgery for Meniere's disease: experience with over 3000 cases. Otolaryngol Clin North Am 2002; 35: 591-606.

16. Ostrowski VB, Kartush JM. Endolymphatic sacvein decompression for intractable Meniere's disease: long-term treatment results. Otolaryngol Head Neck Surg 2003; 128: 550-559.

17. Durland WF Jr, Pyle GM, Connor NP. Endolymphatic sac decompression as a treatment for Meniere's disease. Laryngoscope 2005; 115: 1454-1457.

18. Wetmore SJ. Endolymphatic sac surgery for Meniere's disease: long-term results after primary 
and revision surgery. Arch Otolaryngol Head Neck Surg. 2008 Nov; 134(11): 1144-8.

19. Kitahara T, Kubo T, Okumura S, Kitahara M. Effects of endolymphatic sac drainage with steroids for intractable Meniere's disease. The Laryngoscope 2008; 118: 854-862.

20. Keklik M, Sivgin S, Kaynar L. Treatment with plasma exchange may serve benefical effect in patients with severe hyperbilirubinemia: A single center experience. Transfusion and apheresis science: official journal of the World Apheresis Association: official journal of the European Society for Haemapheresis 2013; 48: 323-326 DOI: 10.1016/j.transci.2013.04.009.

\title{
Резиме
}

\section{ХИРУРШКИ ЗАФАТ НА ЕНДОЛИМФАТИЧНА КЕСА И ФЕНЕСТРАЦИЈА НА ЗАДНИОТ ПОЛУКРУЖЕН КАНАЛ ЗА МЕНИЕРОВА БОЛЕСТ}

\author{
Илија С. Филипче', Марина Давчева Чакар², Венко Филипчеㄹ, Сијаваш Јавари² \\ ${ }^{1}$ Македонска академија на науките и уметностите, Скопје, РС Македонија \\ ${ }^{2}$ Универзитетска клиника за оториноларингологија, Медицински факултет, \\ Универзитет Св. Кирил и Методиј, Скопје, РС Македонија \\ 3 Универзитетска клиника за неврохирургија, Медицински факултет, \\ Универзитет Св. Кирил и Методиј, Скопје, РС Македонија
}

Цел: Да се оцени ефикасноста и безбедноста на истовремената дренажа на ендолимфатичната кеса (ELSD) и фестистрацијата на задниот полукружен канал (PSCF), примарно врз функцијата на вестибулата, како нова терапевтска стратегија кај пациенти со медицински тешко излечивата Мениерова болест (MD).

Дизајн на студијата: Ретроспективна студија на следење.

Локација: Универзитетска клиника за отоларингологија.

Методи: Прегледани се дваесет и шест пациенти со MD со сериозна вртоглавица и попреченост, кои биле подложени на ELSD и PSCF истовремено во периодот од 1988 и 2007 година. Главните мерки со исход беа зачестеноста на вртоглавица, функционална попреченост според упатствата за дијагностицирање и процена на терапијата кај MD. Парезата на каналот е оценета со калориски тест. Степенот на намалена стапка на одговор на вестибуларниот систем како индикатор на вестибуларната функцијата беше спореден пред операцијата и по неа.

Резултати: Предоперативната аудиција веќе беше променета во сите случаи, освен кај 8 пациенти, кои немаа значителни промени во прагот на слухот. Средната вредност на нападите на вртоглавица пред операцијата беше 8,6. По 3 години од операцијата, само еден пациент (3,8 \%) имал еден напад на вртоглавица. Функционалното ниво беше многу подобрено, освен кај двајца пациенти со функционално ниво 2 или В во доцниот постоперативен период. Средното времетраење на калориското тестирање по 3 години постоперативно покажа дека 50 \% од пациентите се приближуваат до нормалните резултати.

Заклучок: Врз основа на резултатите од истовремениот хируршки зафат на ендолимфатична кеса и фенестрација на задниот канал, тоа се ефективни методи на третман на тешко излечивата Мениерова болест. Хируршкиот зафат на ендолимфатичната кеса овозможува дренажа на ендолимфатичната течност, а фенестрацијата на задниот полукружен канал овозможува дистензија или дилатација на мембранозниот канал во декомпримирниот перилимфатичен простор како резултат на перлимфатично истекување низ новиот прозорец, со што се овозможува намалување на ендолипмфатичниот притисок. Двете техники истовремено го намалуваат притисокот во случај на ендолимфатични хидропси.

Клучни зборови: Мениерова болест, тешко излечива вртоглавица, хируршки зафат на ендолимфатична кеса, фенестерација на задниот полукружен канал 